\title{
SUSTAINABILITY ASSESSMENT OF HEAVY METALS AND ROAD MAINTENANCE SALTS IN SWEEP SAND FROM ROADSIDE ENVIRONMENT
}

\author{
Agnė KAZLAUSKIENÉa ${ }^{a}$, Marina VALENTUKEVIČIENE் ${ }^{\mathrm{b}}$, \\ Gytautas IGNATAVIČIUS' \\ a Department of Environmental Protection, Faculty of Environmental Engineering, \\ Vilnius Gediminas Technical University, Sauletekio al. 11, LT-10223 Vilnius, Lithuania \\ ${ }^{\mathrm{b}}$ Department of Water Management, Faculty of Environmental Engineering, \\ Vilnius Gediminas Technical University, Sauletekio al. 11, LT-10223 Vilnius, Lithuania \\ ${ }^{c}$ Centre for Ecology and Environmental Science, Faculty of Nature Sciences, Vilnius University, \\ M. K. Čiurlionio g. 21, LT-03101 Vilnius, Lithuania
}

Received 04 November 2011; accepted 18 December 2012

\begin{abstract}
The main aim of this study was to characterize heavy metal compounds of sweep sand particles in the city of Vilnius (Lithuania). These research results provide new insight into the distribution and variation of heavy metal compounds in sweep sand in the studied area. The results of this investigation reflect the level of heavy metal pollution during the winter season, thus can be used to judge the quality of storm water flowing from streets. The major heavy metals found to have accumulated were lead, nickel, zinc and copper. These research results are useful for conducting preliminary evaluations of possible heavy metal pollution in other similar cities within the European Union.

The general anthropogenic factor of three main types of land-use has the greatest influence on contamination of urban topsoil. In industrial sites, concentrations of key contaminants $(\mathrm{Pb}, \mathrm{Cu}, \mathrm{Mn}, \mathrm{Ni})$ are significantly higher than in residential and public-residential areas.

The present article discussed the significance of systematic sustainable evaluation as one of the most important activities associated with a sustainable approach. Consequently, to reduce a negative effect of salts on street environment, measures of environmentally sustainable development have to be undertaken.
\end{abstract}

Keywords: heavy metals, deicing salts, sweep sand, sustainable development, valuation of environmental effects, environment and development.

Reference to this paper should be made as follows: Kazlauskienè, A.; Valentukevičienė, M.; Ignatavičius, G. 2013. Sustainability assessment of heavy metals and road maintenance salts in sweep sand from roadside environment, Technological and Economic Development of Economy 19(2): 224-236.

JEL classification: Q01, Q25, Q51, Q53, Q56.

Corresponding author Marina Valentukevičienè

E-mail: marina.valentukeviciene@vgtu.lt 


\section{Introduction}

Ecological studies have shown significant exposure-response relationships for adverse pollution effects in association with particulate mass concentrations (Poszyler-Adamska, Czerniak 2007; Staniūnas et al. 2010). Particulate matter has been associated with pollution and fate in urban storm water (Valentukevičienè, Ignatavičius 2011). Ultrafine particles are of particular interest in environment-related studies due to their high concentration in urban environments and the ability to penetrate deep into environmentally sensitive regions of the city (Xia et al. 2004; Christoforidis, Stamatis 2009; Dagiliūtè, Juknys 2012, Kaplanović, Mijailović 2012). Recent ecological studies suggest that adverse response per unit mass is associated more strongly with ultrafine particles rather than fine or coarse particles. Along with particle size, chemical composition influences the pollution of particulate matter (Valentukevičienè, Ignatavičius 2011). There are several types of highly toxic heavy metal compounds in sweep sand including chromium, copper, lead, nickel and other heavy metal compounds, which may have acute effects (Baltrènas, Vaišis 2006). Chlorides and transition metals such as manganese, copper, chromium, and zinc have been shown to generate reactive compounds and can contribute to environmental damage (Jankaitè et al. 2008; Baltrènas, Kazlauskienè 2009). Snow melting salt as well as soil-related materials are thought to be relatively benign, but they may affect the toxicity or bioavailability of other particulate components (Arhami et al. 2009). Because sweep sand is part of a complex multi-component system, it is very difficult to discern a clear association between an adverse effect of pollution and specific chemical components. If pollution effects can be linked to certain sources of particulate matter, such information would be highly valuable for targeting control strategies (Arhami et al. 2009).

As the largest city of Lithuania with approx. 0.5 million of inhabitants, Vilnius is one of the most heavily urbanized regions in Lithuania with multiple traffic and other combustion sources. Studies examining environmental pollution at multiple locations across the region have been conducted since the early 1990s (Staniūnas et al. 2010). Most of studies conducted in Vilnius include as little as few days, a week or two weeks of sampling. Recently, a more comprehensive longer term study was operated by the Vilnius Regional Environmental Protection Department and the Department of Environmental Protection of Vilnius Gediminas Technical University (Lithuania). The results were summarized by Jankaite et al. (2008). The focus of that study was to determine heavy metal concentrations in sweep sand from sampling locations in Vilnius. The former were located in the central, southern, northern, northwestern and western parts of the city. On these streets, deicing salts were mainly used for weather-related emergencies. By contrast, aged sweep sand transported from "source" streets dominates "receptor" areas, located in the southern part of the city.

However, there are not many studies addressing sustainability approach, micro-environmental spatial variation in the chemical composition and physical characteristics of particles in such complex urban environments (Arhami et al. 2009). The objective of this study is to characterize the heavy metal composition of sweep sand particles in the city of Vilnius. Results from the chemical analysis were verified by means of chemical mass closure (CMC) (Sillanpää et al. 2006). These results provide new insight into the distribution and variation of heavy metal compounds in sweep sand in the studied area. 
Heavy metal pollution is a globally significant ecological problem (Kuhn et al. 2005; Bell et al. 2010; Boskidis et al. 2011; Johnson et al. 2011; Mikalajūnè, Jakučionytė 2011). Soil is contaminated by acid rain, heat emissions and heavy metals contained in vehicle exhaust fumes. Heavy metals are detected in agricultural lands and crops as well as various food chains, which causes serious ecological and human health problems (Malik 2004; Gardea-Torresdey et al. 2005; Claus et al. 2007; Prabhat 2008; Vosylienè et al. 2010; Hadam et al. 2011; Hejduk, Banasik 2011; Sawa et al. 2011). The major part of chemical element emissions accumulates in soil as well as stream and lake sediments. Soil is a medium of both contaminant accumulation and contaminant transport. Having entered soil with dust, precipitation, or any other manner, contaminants accumulate in a variety of different combinations. From soil, a pollutant can enter plants and end up in food chains. They can also migrate to surface and ground waters and spread in great distances, re-enter food chains and poison live organisms (Vosylienè et al. 2010). Heavy metals can both migrate and accumulate within soil, often disturbing soil processes and sometimes causing soil degradation (Baltrènas, Vaišis 2006; Poszyler-Adamska, Czerniak 2007). The migration and accumulation of heavy metals in soils depends on several environmental factors, such as meteorological conditions, the chemical and mineralogical composition of soil-forming rocks, the textural composition of the soil, soil solution $\mathrm{pH}$, sorption, and the amount of the soil organic matter (Johnson et al. 2011). The most toxic heavy metal compounds are those containing lead, mercury, cadmium and zinc. However, most of heavy metals - mercury, lead, cadmium, chromium, copper, nickel, zinc, cobalt, vanadium, molybdenum, beryllium, uranium, strontium, arsenic, etc., - have negative effects on health. These include carcinogenic, mutagenic, and teratogenic as well as gonadotoxic, embryotoxical, nefrotoxic and neurotoxic effects. Particularly dangerous is the general synergetic effect of metals, when damage results from separate concentrations within normative values. Subject to the soil characteristics and humidity, heavy metals can cause acidification or alkalinisation of soil and cause diseases and intoxication of various live organisms. Heavy metals are non-biodegradable and therefore persist for long periods of time in both aquatic (Boskidis et al. 2011) and terrestrial environments. They may be transported through soils to reach groundwater or may be taken up by plants, including agricultural crops (Claus et al. 2007).

During the winter season, thousands of tons of deicing and traffic safety improving chemical substances, mainly technical salts (chlorides), are applied to motorways in Lithuania. According to the data published by the Environmental Protection Agency of the Ministry of Environment, more than 14,000 tons of sodium chloride and nearly 16,000 cubic metres of sand and sodium chloride mixture was used on streets of Vilnius to reduce slipperiness during the winter season. Technical salts help ensuring traffic safety in winter but have a negative effect on road environment, especially in cities (Vosyliene et al. 2010; Hejduk, Banasik 2011).

The aim of the research: to determine the concentrations of chloride and heavy metals in sand from streets of Vilnius in the spring season. 


\section{Objects and methods}

The present study focuses on streets of Vilnius. The general anthropogenic factor of three main types of land-use has the greatest influence on contamination of urban topsoil. In industrial sites, concentrations of main contaminants $(\mathrm{Pb}, \mathrm{Cu}, \mathrm{Mn}, \mathrm{Ni})$ are significantly higher than in residential and public-residential areas. In the industrial area, present or former industry is the main direct factor, followed by parking or repair of transport, followed by main traffic loads (Taraškevičius et al. 2008). The street network of Vilnius consists of residential and industrial areas, which has the heaviest traffic in Lithuania and ranks highest for heavy trucks on city streets (Jakimavičius, Burinskienè 2010; Ustinovichius et al. 2011). In addition to urban activities (e.g. individual transport, heavy trucks, locomotives, storage and handling equipment, and local industries), local sources of heavy metal pollution include some of the most heavily travelled motorways in southern Vilnius (international transit plus local street traffic) as well as multiple petroleum storage and other industrial facilities. Besides, Vilnius hosts many smaller industrial and commercial businesses. Thus, the city and the surrounding areas constitute arguably the most complex emission source scenario in Lithuania, and provide the potential for complex pollutant concentration gradients as well as high exposure conditions that cannot be identified by conventional monitoring approaches (Staniūnas et al. 2010).

Eight sampling areas that exhibit different traffic intensities and are located in different parts of Vilnius were selected for this research (Fig. 1).

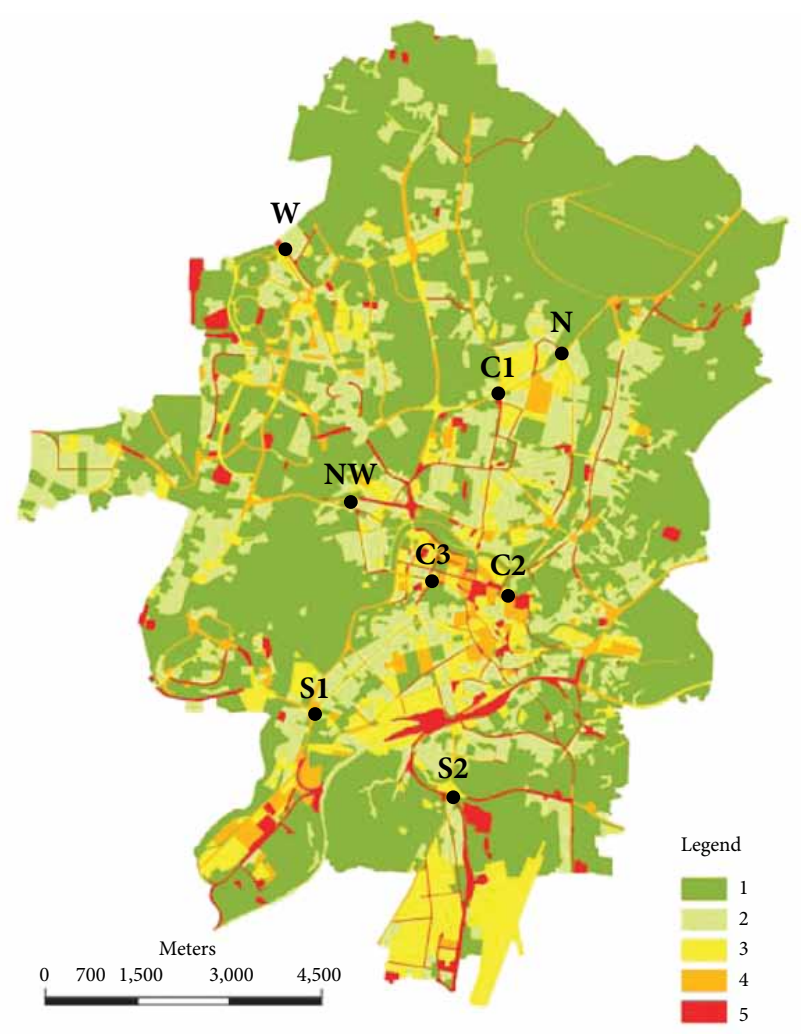

Fig. 1. Sensitivity of territorial units to chemical pollution in the urbanized core of Vilnius. Legend of categories according to scores of sensitivity to chemical pollution (S):

1 - very low $(\mathrm{S} \leq 12.5)$,

2 - low $(12.5<\mathrm{S} \leq 25)$,

3 - medium $(25<\mathrm{S} \leq 37.5)$,

$4-$ high $(37.5<\mathrm{S} \leq 50)$,

5 - very high $(50<\mathrm{S} \leq 80)$

(Jankauskaitè et al. 2008) 
Heavy metal concentrations can represent either quantitative or qualitative variables. Quantitative concentration variables can fulfil permitted values, background of sand and sandy soils (i.e. annual series) or forecasts. The qualitative concentration variables may be applied when dealing with stormwater outlets. The complex method was therefore updated with chloride concentrations. The complex method was used when measuring concentrations between different sampling areas. The centre of area method was applied for comparison. The complex method consists of five parts, namely Central Streets, Southern Streets, Northern Streets, Northern-Western Streets and Western Streets. Accordingly, each of them was modified and updated with results on heavy metal concentrations. The traffic system defines heavy loaded streets (N and S), streets of transit (NW) and conventional urban traffic (C1, C2, C3).

Sweep sand samples were collected from both sides of each sampled street. Stainless steel instruments were used for collecting sweep sand samples for determining heavy metal concentrations; the samples were put into polyethylene string bags. The collected sweep sand samples in string bags (approximately $500 \mathrm{~g}$ in weight) were transported to a certificated laboratory in refrigerator boxes and analysed for quantities of $\mathrm{Cr}, \mathrm{Cu}, \mathrm{Mn}, \mathrm{Ni}, \mathrm{Pb}$ and $\mathrm{Zn}$ using the atomic absorption spectroscopy. The analysis covered these particular heavy metals as they are the main element-indicators linked with contamination caused by motor vehicles. Collected sweep sand samples were then analysed using methods for determination of chloride and heavy metal concentrations approved by International Standards and/or European Norms. Prior to making a chemical analysis, the collected sweep sand samples were dried until constant weight. The sweep sand samples were homogenized passing them through a sieve with $1 \mathrm{~mm}$ sized mesh. $10 \mathrm{~g}$ of sieved out samples were dried at the temperature of $105^{\circ} \mathrm{C}$ for 2 hours and cooled in desiccators. $0.5 \mathrm{~g}$ of sieved out sand sweep sample was weighed with the analytical electronic scale Kern 770-60 (0.0001 g accuracy). The content of $2 \mathrm{ml}$ of hydrogen peroxide $\left(\mathrm{H}_{2} \mathrm{O}_{2}\right)$ and $10 \mathrm{ml}$ of nitric acid $\left(\mathrm{HNO}_{3}\right)$ was used for chemical extraction. All acids were analytical reagent grade obtained from Merck production. Prepared samples were placed in the Milestone Ethos Touch mineraliser's flask to prepare an extract for the next stage of analysis. The sample was held in the mineraliser for 1 hour at $200{ }^{\circ} \mathrm{C}$. Thereafter the vessel with the sample was cooled to a temperature of $50-70{ }^{\circ} \mathrm{C}$ (LST EN 13805:2002). The obtained extract was filtered through a paper filter into a glass flask. This extract was diluted with deionized water up to the mark on the flask $(50 \mathrm{ml})$. All samples were filtered, after their digestion in $\mathrm{H}_{2} \mathrm{O}_{2}-\mathrm{HNO}_{3}$ mixture. This fraction provides only the soluble part of the metal in the oxidized acid mixture under the above conditions (temperature and pressure) in the vessels. Metal concentrations were measured with the spectrometer Buck Scientific 210 VGP using the acetylene-air flame (Jankaite et al. 2008). Two quality control blanks are carried along with each batch. Reference material is run after two blanks. Subsequent certified reference materials were used repeatedly to verify the method results. To evaluate the soil contamination level, laboratory analytical results were compared with heavy metal background concentrations for Lithuanian soils, as approved by the National Hygiene Norm "The Maximum Permissible Concentrations of Hazardous Chemical Substances in Soil" (HN 60:2004). The samples taken for analysis from street-sides were of sand and sandy loam. Standard background concentrations for heavy metals are: $\mathrm{Ni}-12 \mathrm{mg} / \mathrm{kg}, \mathrm{Pb}-15 \mathrm{mg} / \mathrm{kg}$, 
$\mathrm{Cu}-8.1 \mathrm{mg} / \mathrm{kg}, \mathrm{Cr}-30 \mathrm{mg} / \mathrm{kg}, \mathrm{Zn}-26 \mathrm{mg} / \mathrm{kg}, \mathrm{Mn}-427 \mathrm{mg} / \mathrm{kg}$. The maximum permissible concentrations (MPC) of heavy metals in soil are: $\mathrm{Ni}-75 \mathrm{mg} / \mathrm{kg}, \mathrm{Pb}-100 \mathrm{mg} / \mathrm{kg}$, $\mathrm{Cu}-100$ mg/kg, Cr - 100 mg/kg, Zn - 300 mg/kg, Mn - 1500 mg/kg (HN 60:2004).

Sweep sand samples, collected from the sides of streets, were dried and divided into $100 \mathrm{~g}$ portions to prepare for chloride analysis. The sweep sand samples prepared using the same procedure were placed in glass vessels, to which $200 \mathrm{ml}$ of $5 \% \mathrm{HNO}_{3}$ solution was added, and then placed in a roto-shaker Gerhardt Rotoshaker RS12 for one hour (20 rotations/min). The settled samples were taken out of the shaker, filtered via a paper filter and poured into a $250 \mathrm{ml}$ conical flask, in $100 \mathrm{ml}$ portions. $1 \mathrm{ml}$ of $\mathrm{K}_{2} \mathrm{CrO}_{4} 10 \%$ was poured into each sample and titrated with $\mathrm{AgNO}_{3} 0.02 \mathrm{~mol} / \mathrm{l}$ solution until the colour of a sample turned from yellowish to orange. The chloride concentrations established by the titrimetric analysis are expressed and presented in $\mathrm{mg} / \mathrm{kg}$ (Vainalavičiūte et al. 2009). To obtain chloride concentrations, sweep sand samples were taken from both sides of each street. The sand used for road maintenance during winter already contained a background concentration of $15 \mathrm{mg} / \mathrm{kg}$ chloride (Vilnius Regional Environmental Protection Department). An error of $15 \%$ marked in diagrams is possible when measuring chloride concentrations by the titrimetric method of chemical analysis (LST EN 1744-1:2010).

All results obtained from this research are presented as the arithmetic mean of six independent measurements $(x \pm \mathrm{SD}, n=6)$. Significant differences $(p<0.05)$ were removed from the result estimations and the measurements were analyzed once again. The concentration of heavy metals and chloride was measured 11 times. The average concentration at typical points was:

$$
\bar{c}=\frac{1}{n} \sum_{i=1}^{k} c_{i} m_{i},
$$

where: $c_{i}$ - concentration of substances at typical points; $m_{i}$ - probability at the occurrence of concentration; $n$ - number of days; $k$ - number of different values of the concentration.

The average concentrations of substances, mentioned above, at the characteristic point were calculated as well. The standard statistical estimation error of the arithmetic average was approximately $11 \%$. The dependencies between different compound concentrations and all indicators in different samples were determined by statistical analysis using Mathcad 2001 Professional software.

\section{Results and discussion}

The results of this investigation reflect the level of heavy metal pollution during the winter season, thus results can be used to judge the quality of stormwater flowing from streets. These research results are useful for conducting preliminary evaluations of possible heavy metal pollution in other similar cities within the European Union. The major heavy metals found to have accumulated were lead, nickel, zinc and copper, each of which was found in concentrations between 2 and 5 times higher compared to background concentrations for these metals. Chloride concentrations were found to be between 4 and 40 times greater compared to the background concentration. 
Both manganese and chromium concentrations were approximately 2-3 times lower compared to their background concentrations in sand and sandy loam soils. Chloride and lead concentrations were nine times and 70 percent of their background concentrations, respectively, whereas other elements were found to be approx. 50 percent of their background concentrations. At one site located on a Northern Street $(\mathrm{N})$, the maximum value of lead contribution was approx. 30\% higher compared to that measured at Central Streets (C1, C3). This site was strongly influenced by vehicle exhaust emissions (Tchepel et al. 2012) resulting from heavy traffic load (Baltrènas, Vaišis 2006; Jankaitè et al. 2008; Staniūnas et al. 2010).

The sand additive contamination index $\mathrm{Zd}$ (HN 60:2004) was calculated according to concentration coefficients of 7 elements (Jankauskaite et al. 2008). The total contamination index $(\mathrm{Zd})$ evaluating the content of heavy metals and chloride in sand sweeps was: $\mathrm{W}(\mathrm{Zd}=13.35)>>\mathrm{C} 1(\mathrm{Zd}=12.24)>>\mathrm{C} 2(\mathrm{Zd}=9.86)>>\mathrm{C} 3(\mathrm{Zd}=8.37)>>\mathrm{N}(\mathrm{Zd}=6.48)>>$ $\mathrm{NW}(\mathrm{Zd}=5.29)>>\mathrm{S} 1(\mathrm{Zd}=4.72)>>\mathrm{S} 2(\mathrm{Zd}=4.02)$.

Manganese concentrations in sweep sand sampled from N, S1, NW, C1, W, C3 was approximately $200.0 \mathrm{mg} / \mathrm{kg}$ and did not exceed Maximum Permissible Concentrations (MPC) or the background concentrations $(427 \mathrm{mg} / \mathrm{kg}$ ). Manganese was somewhat below the average $(155.53 \mathrm{mg} / \mathrm{kg})$ at (C2) in the Old Town, but exceeded the average by nearly 2 times in the southern part of the city (S2, 334.22 $\mathrm{mg} / \mathrm{kg})$.

Concentrations of $\mathrm{Zn}$, close to MPC in sweep sand were obtained in the western (W) and central $(\mathrm{C} 1-\mathrm{C} 3)$ parts of the city, while lower values were observed in the northern $(\mathrm{N})$ part of the city. However, concentration of $\mathrm{Zn}$ in sweep sand was always higher than the background concentration $(26 \mathrm{mg} / \mathrm{kg})$ (Table 1$)$.

Table 1. Heavy metal (mg/kg) distribution among the investigated area (Perm. - permitted concentration $\mathrm{mg} / \mathrm{kg}$, Bg. - background concentration $\mathrm{mg} / \mathrm{kg}$ of sand and sandy loam soils)

\begin{tabular}{|c|c|c|c|c|c|c|c|c|c|c|}
\hline Heavy metal & $\mathrm{N}$ & NW & $\mathrm{C} 1$ & C2 & C3 & W & S1 & S2 & Perm. & Bg. \\
\hline $\mathrm{Mn}_{\text {mean }}$ & 230.56 & 198.46 & 190.82 & 155.53 & 199.74 & 191.45 & 183.95 & 334.22 & & \\
\hline $\mathrm{Mn}$ min & 180.00 & 182.40 & 176.16 & 136.12 & 178.14 & 176.13 & 165.15 & 306.54 & 1500 & 427 \\
\hline $\mathrm{Mn}_{\text {max }}$ & 230.84 & 225.18 & 210.14 & 167.84 & 215.20 & 210.45 & 197.18 & 350.86 & & \\
\hline $\mathrm{Zn}_{\text {mean }}$ & 59.92 & 106.48 & 281.16 & 210.56 & 184.86 & 290.72 & 76.34 & 85.37 & & \\
\hline $\mathrm{Zn}$ min & 47.17 & 74.68 & 257.14 & 174.15 & 158.87 & 274.18 & 52.12 & 62.11 & 300 & 26 \\
\hline $\mathrm{Zn}_{\text {max }}^{\text {min }}$ & 79.02 & 128.63 & 312.43 & 240.19 & 204.76 & 326.43 & 97.36 & 110.23 & & \\
\hline $\mathrm{Cr}_{\text {mean }}$ & 9.13 & 9.67 & 26.45 & 22.37 & 24.58 & 28.72 & 11.55 & 5.92 & & \\
\hline $\mathrm{Cr}^{\text {mean }}$ & 6.14 & 6.75 & 22.52 & 19.16 & 21.17 & 25.34 & 7.86 & 4.67 & 100 & 30 \\
\hline $\mathrm{Cr}_{\max }^{\min }$ & 12.77 & 13.08 & 28.13 & 24.56 & 26.46 & 31.25 & 13.62 & 8.26 & & \\
\hline $\mathrm{Cu}_{\text {mean }}$ & 13.72 & 12.24 & 17.45 & 16.84 & 11.56 & 16.23 & 16.66 & 14.45 & & \\
\hline $\mathrm{Cu}^{\text {mean }}$ & 10.12 & 9.87 & 14.77 & 15.03 & 7.87 & 13.59 & 14.36 & 11.64 & 100 & 8.1 \\
\hline $\mathrm{Cu}_{\max }{ }^{\min }$ & 15.68 & 14.53 & 20.16 & 19.47 & 14.12 & 18.96 & 19.11 & 17.46 & & \\
\hline $\mathrm{Pb}$ & 71.67 & 35.52 & 25.41 & 41.84 & 21.16 & 25.84 & 48.25 & 22.35 & & \\
\hline $\mathrm{Pb}_{\text {mean }}$ & 54.16 & 31.58 & 22.15 & 36.40 & 17.69 & 22.45 & 45.71 & 18.09 & 100 & 15 \\
\hline $\mathrm{Pb}_{\text {max }}^{\min }$ & 87.36 & 38.16 & 27.87 & 45.28 & 23.15 & 28.75 & 52.13 & 23.17 & & \\
\hline $\mathrm{Ni}$ & 22.53 & 18.81 & 15.16 & 9.72 & 25.57 & 24.44 & 27.67 & 17.85 & & \\
\hline $\mathrm{Ni}^{\text {mean }}$ & 19.16 & 17.84 & 12.61 & 7.68 & 21.78 & 21.47 & 24.41 & 16.01 & 75 & 12 \\
\hline $\mathrm{Ni}_{\max }^{\mathrm{min}}$ & 24.25 & 22.08 & 18.13 & 12.32 & 28.16 & 26.85 & 29.68 & 19.88 & & \\
\hline
\end{tabular}

Explanation: C1, C2, C3 - Central Streets; S1, S2 - Southern Streets and N - Northern Streets; NW Northern-Western Streets and W - Western Streets sampling areas. 


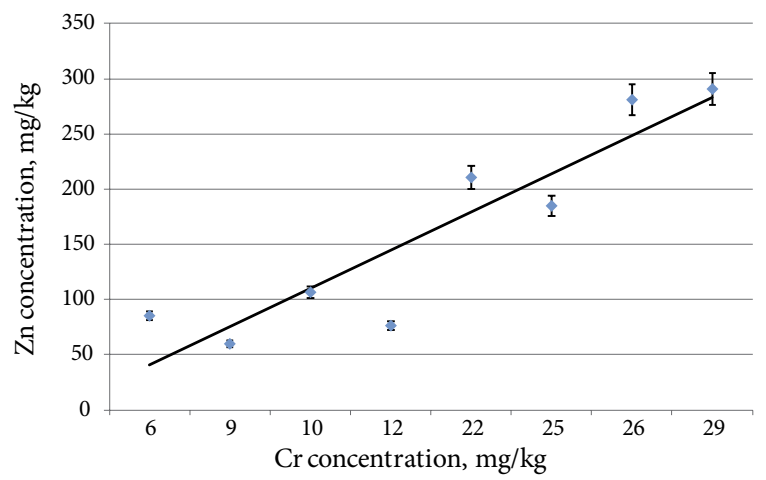

Fig. 2. Relationship between zinc and chromium concentrations in sweep sand

The concentrations of $\mathrm{Cr}$ in sweep sand from streets of the central (C1) and western (W) parts of the city were close to the background concentration $(30 \mathrm{mg} / \mathrm{kg})$ and did not exceed the MPC (100 mg/kg) (Table 1).

Concentrations of both zinc and chromium transition metals were found to increase in linear dependency (Fig. 2). Both metals are used extensively in different parts of vehicles because of their anticorrosion properties. Zinc is used in wider applications compared to chromium and was found present in sweep sand samples in concentrations 10 times higher than chromium. In case of both metals, the observed dependency between zinc and chromium can be explained as the result of the destructive impact of deicing sand-salt admixture on vehicle anticorrosive layers (Petkuviené, Paliulis 2009). In street sweep sand samples for all streets sampled within this study, zinc concentrations $\left(\mathrm{C}_{\mathrm{Zn}}\right)$ were found to be related to chromium concentrations $\left(\mathrm{C}_{\mathrm{Cr}}\right)$; according to Eq. $2, \mathrm{R}^{2}=0.84$.

$$
\mathrm{C}_{\mathrm{Zn}}=34.68 \cdot \mathrm{C}_{\mathrm{Cr}}+5.87 \text {. }
$$

This dependency can be useful for making preliminary predictions of zinc and/or chromium quantities in street sweep sands.

The concentrations of $\mathrm{Cu}$ in all the sweep sand samples under investigation exceeded the background concentration $(8.1 \mathrm{mg} / \mathrm{kg})$ from 1.42 to 2.15 times, but did not exceed the MPC. $\mathrm{Cu}$ concentrations in the central part of the city are distributed unevenly as the highest value $(17.45 \mathrm{mg} / \mathrm{kg})$ was observed in $\mathrm{C} 1$, while the lowest $(11.56 \mathrm{mg} / \mathrm{kg})$ was observed in C3.

The concentration of $\mathrm{Ni}$ in all samples did not exceed the MPC (Table 1), but the background concentration $(12 \mathrm{mg} / \mathrm{kg}$ ) was exceeded in all but one sample (C2) from the central part of the city. The highest excess (approx. twice background) was found in the southern part (S1), western part (W) and one location of the central part of the city (C3).

Lead concentrations did not exceed the MPC $(100 \mathrm{mg} / \mathrm{kg})$, but exceed the background concentration $(15 \mathrm{mg} / \mathrm{kg})$ in all samples by a factor of $1.41-4.77$. The highest excess was found in the northern $(\mathrm{N})$ part of the city $-71.67 \mathrm{mg} / \mathrm{kg}$; while the lowest was discovered in the central (C3) part of the city (Table 1). The concentrations of both lead and chloride species were highly correlated across all minimum and maximum ranges, with $\mathrm{R}^{2}$ values 


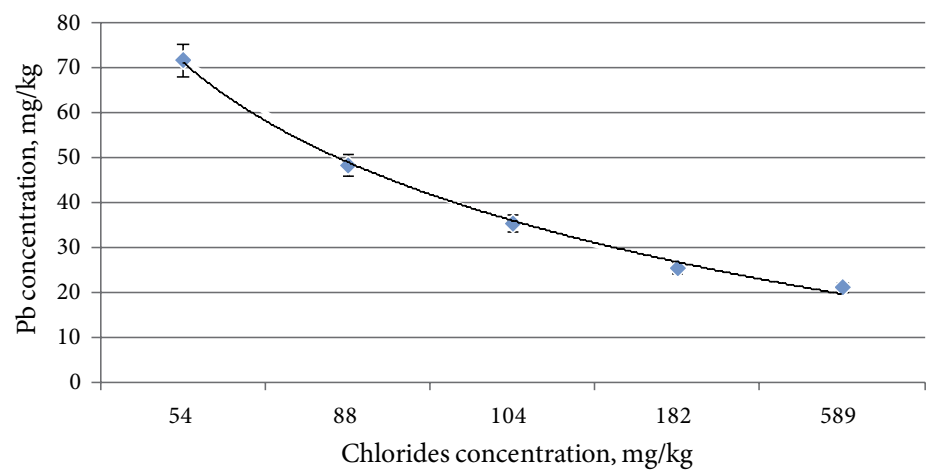

Fig. 3. Relationship between lead and chloride concentrations in sweep sand

amounting to approx. 0.93. Lead and chloride are substantially higher than the background concentration, supporting the argument that these elements are related to each other in sweep sand particles (Fig. 3). The earliest study clearly demonstrated that a large part of the $\mathrm{Pb}$ was present in chemical fractions that are vulnerable to leaching when exposed to high $\mathrm{NaCl}$ concentration (Norrström, Jacks 1998).

Chloride concentrations increased in all samples, when lead was decreased in logarithmic dependency. Lead concentrations $\left(\mathrm{C}_{\mathrm{Pb}}\right)$ in sweep sand samples for all streets sampled within this study were found to be related to chloride concentrations $\left(\mathrm{C}_{\mathrm{Cl}}\right)$ using Equation 3 .

$$
\mathrm{C}_{\mathrm{Pb}}=-24.73 \cdot \ln \left(\mathrm{C}_{\mathrm{Cl}}\right)+68.62 .
$$

The explanation of this observed dependency relies on the use of significant amounts of deicing salts (chloride based), after which large amounts of melted snow flows off the street resulting in decreased lead concentrations, while increasing chloride accumulation in sweep sands. This hypothesis explains the relationship between lead and chloride in sweep sand samples, when compound solubility mechanism accounts for preferential retardation of lead.

There was no significant correlation $(p<0.05)$ between chloride and Ni with $\mathrm{Mn}$ and $\mathrm{Zn}$ independently in different sampling areas collected sweep sand (Table 2).

Table 2. Compliance with sustainable urban development

\begin{tabular}{ll}
\hline Study Results & Improvements \\
\hline $\begin{array}{l}\mathrm{Zn}, \mathrm{Cu}, \mathrm{Pb}, \mathrm{Ni}, \mathrm{Cl}-\text { concentrations exceed } \\
\text { the background concentration }\end{array}$ & $\begin{array}{l}\text { Control deicing salts application and heavy } \\
\text { traffic volumes }\end{array}$ \\
\hline $\begin{array}{l}\mathrm{Mn}, \mathrm{Cr} \text { concentrations below the background } \\
\text { concentration }\end{array}$ & Continues annual monitoring \\
\hline $\mathrm{Mn}, \mathrm{Zn}, \mathrm{Cr}, \mathrm{Cu}, \mathrm{Pb}, \mathrm{Ni}$ concentrations below MPC & Continues monthly monitoring \\
\hline $\begin{array}{l}\text { Reliable dependencies of Pb concentrations } \\
\text { on Cl- concentrations }\end{array}$ & $\begin{array}{l}\text { Control deicing salts application and vehicles } \\
\text { traffic on streets }\end{array}$ \\
\hline Sustainable use of deicing salts & \\
\hline Development of environmentally friendly transport systems \\
\hline Sustainable urban development
\end{tabular}


With regard to the MPC, heavy metals present in different samples result in the same element appearance order: $\mathrm{Pb}>\mathrm{Ni}>\mathrm{Zn}>\mathrm{Mn}>\mathrm{Cu}>\mathrm{Cr}$. All samples evaluated with regard to the background concentration show a different order between similar first and last $\mathrm{Pb}$ and $\mathrm{Cr}$ respectively: $\mathrm{Pb}>\mathrm{Zn}>\mathrm{Ni}>\mathrm{Cu}>\mathrm{Mn}>\mathrm{Cr}$. Some results confirm that lead is always the most common metal, followed by $\mathrm{Zn}$. Lead raises most of concerns in terms of environmental heavy metal pollution (Christoforidis, Stamatis 2009).

The absence of dependencies between chloride and nickel or manganese supports the argument that transport is not the major source of these metals in sweep sands. Slightly higher, but still insignificant correlations were found between chloride and chromium as well as copper, which may be explained by contribution of vehicular sources to $\mathrm{Cr}$ and $\mathrm{Cu}$ concentrations in addition to different components of asphalt mixtures (Sofilić et al. 2011).

\section{Conclusions}

According to sustainable development method, background concentrations of heavy metals rely on concentrations obtained and estimated in sand and sandy loam silts as well as the measurement of chloride concentrations between certain sampling areas of a selected point and every alternative.

The present article discussed the significance of the use of systematic sustainable evaluation that involves an environmental engineering specialist as one of the most important activities associated with the improvement of the sustainable approach. Environmental specialists have considered the sustainability of environmental evaluation from the point of view of environmental impact assessment putting the emphasis on the fact that the living environment is a complex multi-level system, which needs to be assessed as an integrated aggregate in the context of a wide-ranging model (Bożejko et al. 2012).

As an example of the application of the sustainable development approach, the rankings of the environmental assessment method of complex evaluation were estimated into a dependency reliable scale based on lead and chloride concentrations in swept sand. The lead concentrations measured in swept sands indicated a significant dependency on chloride concentrations.

The necessity to respond to the real deicing admixture needs has forced all European environmental protection institutions to use the sustainable approach when conducting an environmental impact assessment. In case of using the minimum required amount of deicing salts in conjunction with immediate removal systems, all measured heavy metals and chloride concentrations will correspond to the European and national legislation.

A sustainability assessment of the quality of the living environment can thus serve as an efficient instrument for generating information necessary for evaluation and development of a proper strategy for improvement of urban environment and creation of a system of sustainable environmental support aimed at enhancing the quality of the living environment.

Consequently, to reduce a negative effect of salts on the street environment, measures for environmentally sustainable development have to be undertaken. To achieve a balanced use of salts, application of alternative materials (e.g. molasses-based materials) is proposed. The introduction of biotechnical measures (biological and chemical methods) is sufficient to eliminate the consequences of the excessive use of deicing salts, but not the reasons for their use. It would be useful to investigate the specificity of the use of these materials under Lithuanian climatic and geographical conditions. 


\section{References}

Arhami, M.; Sillanpää, M.; Hu, S.; Olson, M. R.; Schauer, J. J.; Sioutas, C. 2009. Size-segregated inorganic and organic components of PM in the communities of the Los Angeles harbour, Aerosol Science and Technology 43(2): 145-160. http://dx.doi.org/10.1080/02786820802534757

Baltrènas, P.; Kazlauskiené, A. 2009. Sustainable ecological development reducing negative effects of road maintenance salts, Technological and Economic Development of Economy 15(1): 178-188. http://dx.doi.org/10.3846/1392-8619.2009.15.178-188

Baltrenas, P.; Vaišis, V. 2006. Research in to soil contamination by heavy metals in the northern part of the Klaipeda city, Lithuania, Geologija 55: 1-8.

Bell, T.; Campbell, S.; Liverman, D. G. E.; Allison, D.; Sylvester, P. 2010. Environmental and potential human health legacies of non-industrial sources of lead in a Canadian urban landscape - the case study of St John's, Newfoundland, International Geology Review 52(7-8): 771-800. http://dx.doi.org/10.1080/00206811003679786

Boskidis, I.; Gikas, G. D.; Sylaios, G.; Tsihrintzis, V. A. 2011. Water quantity and quality assessment of lower Nestos river, Greece, Journal of Environmental Science and Health, Part A, 46(10): 1050-1067.

Bożejko, W.; Hejducki, Z.; Wodecki, M. 2012. Applying metaheuristic strategies in construction projects management, Journal of Civil Engineering and Management 18(5): 621-630.

http://dx.doi.org/10.3846/13923730.2012.719837

Christoforidis, A.; Stamatis, N. 2009. Heavy metal contamination in street dust and roadside soil along the major national road in Kavala's region, Greece, Geoderma 151: 257-263.

http://dx.doi.org/10.1016/j.geoderma.2009.04.016

Claus, D.; Dietze, H.; Gerth, A.; Grosser, W.; Hebner, A. 2007. Application of agronomic practice improves phytoextraction on a multipolluted site, Journal of Environmental Engineering and Landscape Management 15(4): 208-212.

Dagiliūte, R.; Juknys, R. 2012. Eco-efficiency: trends, goals and their implementation in Lithuania, Journal of Environmental Engineering and Landscape Management 20(4): 265-272. http://dx.doi.org/10.3846/16486897.2012.661072

Gardea-Torresdey, J. L.; Peralta-Videa, J. R.; de la Rosa, G.; Parsons, J. G. 2005. Phytoremediation of heavy metals and study of the metal coordination by X-ray absorption spectroscopy, Coordination Chemistry Reviews 249(17-18): 1797-1810. http://dx.doi.org/10.1016/j.ccr.2005.01.001

Jakimavičius, M.; Burinskiené, M. 2010. Route planning methodology of an advanced traveller information system in Vilnius city, Transport 25(2): 171-177. http://dx.doi.org/10.3846/transport.2010.21

Jankaitè, A.; Baltrènas, P.; Kazlauskienè, A. 2008. Heavy metal concentrations in roadside soils of Lithuania’s highways, Geologija 4(64): 237-245. http://dx.doi.org/10.2478/v10056-008-0049-7

Jankauskaite, M.; Taraškevičius, R.; Zinkute, R.; Veteikis, D. 2008. Relationship between landscape selfregulation potential and topsoil additive contamination by trace elements in Vilnius city, Journal of Environmental Engineering and Landscape Management 16(1): 5-14. http://dx.doi.org/10.3846/1648-6897.2008.16.5-14

Johnson, B.; Zhang, Z.; Velleux, M.; Julien, P. Y. 2011. Development of a distributed watershed contaminant transport, transformation, and fate (CTT\&F) sub-model, Soil and Sediment Contamination: an International Journal 20(6): 702-721. http://dx.doi.org/10.1080/15320383.2011.594111

Kaplanović, Ž.; Mijailović, R. 2012. The internalisation of external costs of $\mathrm{CO}_{2}$ and pollutant emissions from passenger cars, Technological and Economic Development of Economy 18(3): 470-486. http://dx.doi.org/10.3846/20294913.2012.702694

Kuhn, T.; Biswas, S.; Fine, P. M; Geller, M.; Sioutas, C. 2005. Physical and chemical characteristics and volatility of PM in the proximity of a light-duty vehicle freeway, Journal of Aerosol Science 39(4): 347-357. http://dx.doi.org/10.1080/027868290930024 
Hadam, A.; Wrochna, M.; Karaczun, Z. 2011. Effect of hydrogel on the turf grass species growing under salt stress, Annals of Warsaw University of Life Science -SGGW, Land Reclamation 43(1): 47-55.

Hejduk, A.; Banasik, K. 2011. Recorded lag times of snowmelt events in a small catchment, Annals of Warsaw University of Life Sciences - SGGW, Land Reclamation 43(1): 37-46.

HN 60:2004. Maximum permissible concentrations of hazardous chemical materials in soil, Valstybes zinios 41-1357 (in Lithuanian).

LST EN 13805:2002. Foodstuffs - Determination of trace elements - Pressure digestion. 9 p.

LST EN 1744-1:2010. Tests for chemical properties of aggregates - Part 1: Chemical analysis. $62 \mathrm{p}$.

Malik, A. 2004. Metal bioremediation through growing cells, Environmental International 30(2): 261-278. http://dx.doi.org/10.1016/j.envint.2003.08.001

Mikalajūnè, A.; Jakučionyte, L. 2011. Investigation into heavy metal concentration by the gravel roadsides, Journal of Environmental Engineering and Landscape Management 19(1): 89-100.

http://dx.doi.org/10.3846/16486897.2011.557474

Norrström, A. C.; Jacks, G. 1998. Concentration and fractionation of heavy metals in roadside soils receiving deicing salts, Science of the Total Environment 218(2-3): 161-174. http://dx.doi.org/10.1016/S0048-9697(98)00203-4

Petkuvienė, J; Paliulis, D. 2009. Experimental research of road maintenance salts and molasses ("Safecote") corrosive impact on metals, Journal of Environmental Engineering and Landscape Management 17(4): 236-243. http://dx.doi.org/10.3846/1648-6897.2009.17.236-243

Poszyler-Adamska, A.; Czerniak, A. 2007. Biological and chemical indication of roadside ecotone zones, Journal of Environmental Engineering and Landscape Management 15(2): 113a-118a.

Prabhat, K. R. 2008. Heavy metal pollution in aquatic ecosystems and its phytoremediation using wetland plants: an ecosustainable approach, International Journal of Phytoremediation 10(2): 133-160. http://dx.doi.org/10.1080/15226510801913918

Sawa, K.; Hejduk, L.; Deelstra, J.; Øygarden, L. 2011. Nutrient output from rural areas on the example of two catchments Skuterud and Zagożdżonka, Annals of Warsaw Uniersity of Life Sciences - SGGW, Land Reclamation 43(1): 71-85.

Sillanpää, M.; Hillamo, R.; Saarikoski, S.; Frey, A.; Pennanen, A.; Makkonen, U.; Spolnik, Z.; Van Grieken, R.; Branis, M.; Brunekreef, B.; Chalbot, M. C.; Kuhlbusch, T.; Sunyer, J.; Kerminen, V. M.; Kulmala, M.; Salonen, R. O. 2006. Chemical composition and mass closure of particulate matter at six urban sites in Europe, Atmospheric Environment 40: S212-S223. http://dx.doi.org/10.1016/j.atmosenv.2006.01.063

Sofilić, T.; Mladenovič, A.; Sofilić, U. 2011. Defining of EAF steel slag application possibilities in asphalt mixture production, Journal of Environmental Engineering and Landscape Management 19(2): 148-157. http://dx.doi.org/10.3846/16486897.2011.580910

Staniūnas, M.; Staniūnas, E. K.; Burinskienė, M. 2010. Application of indices for assessing the ecological potential of urban development, Ekologija 56(3-4): 79-86. http://dx.doi.org/10.2478/v10055-010-0011-y

Taraškevičius, R.; Zinkute, R.; Jankauskaite, M. 2008. Differences of Vilnius topsoil contamination in the Neris River valley due to anthropogenic factors, Geologija 50, 3(63): 135-142.

Tchepel, O.; Dias, D.; Ferreira, J.; Tavares, R.; Miranda, A. I.; Borrego, C. 2012. Emission modelling of hazardous air pollutants from road transport at urban scale, Transport 27(3): 299-306. http://dx.doi.org/10.3846/16484142.2012.720277

Ustinovichius, L.; Barvidas, A.; Vishnevskaja, A.; Ashikhmin, I. V. 2011. Multicriteria verbal analysis of territory planning system's models from legislative perspective, Journal of Civil Engineering and Management 17(1): 16-26. http://dx.doi.org/10.3846/13923730.2011.554173

Vainalavičiūtè, R.; Kazlauskienè, A.; Baltrenas, P.; Jankaitė, A. 2009. Investigation of particulate matter and chloride concentrations in the environment of gravelled roads, Geologija 51, 1(65): 1-11. 
Valentukevičienè, M.; Ignatavičius, G. 2011. Analysis and evaluation of the effect of the solids from road surface runoff on the sediments of river bed, Ekologija 57(1): 39-45. http://dx.doi.org/10.6001/ekologija.v57i1.1308

Vosylienė, M. Z.; Kazlauskienè, A.; Mikalajūnè, A. 2010. Alterations in selected haematological parameters of rainbow trout (Oncorhynchus mykiss) exposed to complex mixtures of contaminants, Environment Protection Engineering 36(4): 95-104.

Xia, T.; Korge, P.; Weiss, J. N.; Li, N.; Venkatesan, M. I.; Sioutas, C.; Nel, A. 2004. Quinones and aromatic chemical compounds in particulate matter induce mitochondrial dysfunction: implications for ultrafine particle toxicity, Environmental Health Perspectives 112(14): 1347-1358.

http://dx.doi.org/10.1289/ehp.7167

Agne KAZLAUSKIENĖ is an Associate Professor of Vilnius Gediminas Technical University. Research interests: environmental protection, gravel road dustiness, environmental pollution with road maintenance salt, antipollution of road environment, vegetation preservation.

Marina VALENTUKEVIČIENĖ is an Associate Professor of Vilnius Gediminas Technical University and European projects evaluator for the EC. Research interests: eco-friendly water treatment technologies, sustainable use of water resources, environmental impact assessment, water reuse technologies, sustainable living environment.

Gytautas IGNATAVIČIUS is Associate Professor of the Centre for Ecology and Environmental Science, Faculty of Natural Sciences, Vilnius University. Research interests: eco-friendly environmental engineering technologies, sustainable use of natural resources, environmental impact assessment, sustainable living environment. 